Adam Koronowski*

\title{
Monetary Policy and Financial (In)Stability
}

Submitted: March $24^{\text {th }}, 2010$

Accepted: May $28^{\text {th }}, 2010$

\section{Summary}

This paper presents how monetary policy, restricted only by price stability, may easily become propitious to asset inflation and - eventually - to a financial crisis. This risk is particularly high when the financial system lacks proper regulation and effective supervision. Hasty liberalization, negligence of official oversight and „Greenspan doctrine" which refuted any activist policy promoting financial stability characterized Fed's monetary policy under the former Fed's governor. The paper also analyses another aspect of the linkages between monetary policy and financial crises - monetary policy reaction to financial crises. It is not surprising that it consists of cutting interest rates and bail-out of insolvent, systemically important financial institutions. Such policy, especially when run too long and changed too abruptly, not only creates moral hazards but it also sets the stage for another ,, search for yield” and build-up of another speculative bubble. As a result, monetary policy becomes asymmetric and pro-cyclical. Fed's reaction to the recent crisis seems to be very much in line with this pattern typical of Fed's policy in the past. However, this time the scale of flooding the economy with liquidity and - as a consequence - the risks of future major imbalances in the financial system are unprecedented. A general conclusion of the paper says that there can't be a sound financial and economic system unless money itself is a scarce resource. However trivial this statement is, monetary policy of some central banks seems to miss the point.

\section{Introduction}

There is broad literature on the subject whether central banks should react to - and are able to identify - any signs of financial misalignments or asset price bubbles. The

* Dr hab., prof. nadzw., Wyższa Szkoła Finansów i Zarządzania w Siedlcach. 
answers provided have been different. The axis of the problem is the dilemma: is price stability enough or should central banks pursue monetary policy in a more compound manner. After more than a decade of the dominance of direct inflation targeting - explicit or implicit - this question is now more important than ever. I am inclined to share the opinions that monetary policy may be lax even though it guaranties price stability. The result may be fuelling a speculative mania. Moreover, another aspect of monetary policy is the way a central bank reacts to a financial crisis and financial instability. In these days central banks run their policy under the pressure of the dynamic circumstances of financial instability rather than inspired by an intellectual reflection. The result is not a lax monetary policy any more, this is a helicopter money policy. Is it possible to have a sound financial system and strong economy where money is for nothing?

The aim of this paper is to reconsider a negative role that monetary policy can play in dismantling reasonable incentives and restrictions in the investment process. This is a policy paper which is practically oriented. It is intended to reassess the present dominant pattern of monetary policy which in good times is single-mindedly oriented at price stability and in times of a crisis it is predominantly devoted to the supply of virtually unlimited liquidity to avoid a collapse of the financial system, credit crunch and recession. The paper does not build upon any ,stylized facts”, it looks just at facts, particularly at the American experience which is the clearest and most meaningful. Of course, interpretation of the facts may not necessarily be obvious. However, any modeling would not help much in this respect. In the paper I give an example of an academic model where a naïve presumption leads to fault results. Due to the scope of the data and the character of the phenomena analyzed, quantitative analysis does not seem to provide decisive insights, either, although some useful efforts are made (ex. Mishkin and White, 2002).

This paper is organized as follows; the next, second part briefly presents the reasons for financial crises. It does not provide extensive answers, it rather sets the stage for the main issue. The third part presents the discussion on the role of monetary policy in the face of financial imbalances and it claims that - having not reacted correctly - monetary policy may fuel a speculative mania. The fourth part tries to establish a link between the way central banks used to manage financial instability and creating prerequisites for another crisis. It also describes in this context the recent steps taken by the Fed. The paper concludes with a short summary.

\section{What are the reasons for financial distress?}

An answer to the question about the reasons for financial distress may be trivial. The substance of any financial crisis is an immense and rapid decline in the value of a category of assets. Such a decline is a result of an earlier asset price bubble when the prices were not justified by fundamental factors ( incomes which these assets could be reasonably expected to provide). Shortly speaking, the reason is always ,irrational exuberance” using Greenspan's terminology or a „speculative mania” according to Kindleberger.

Such an explanation, however trivial, is in contradiction to the efficient market hypothesis. It is not the purpose of this paper to discredit the hypothesis; it is clear that in 
spite of its formal elegance it proved to be misleading in the perception of the functioning of financial markets. This is a matter of fact. However, an explanation why markets are not efficient and ,irrational exuberance” or „speculative manias” happen is not so trivial any more. This is, first of all, subject to the behavioral theory of finance. Leaving apart academic theories let's take here for granted that investors not necessarily make rational decisions and markets not always, if ever, are effective. Asset price bubbles are a phenomenon difficult to deny. Instead of analyzing in what regard human beings are not perfectly rational let's try to identify factors propitious to build-up of financial imbalances.

Firstly, keeping in mind the purpose of the paper, it is useful to notice that speculative manias took place under the gold standard, too; consider the „tulip mania” in Holland in the 17th century or the collapse of the East India Company in England. It proves that an active interest rate policy of a modern central bank is not a necessary condition for a crisis. However, it does not say that monetary policy can't be a propitious or even sufficient factor to bring about financial distress.

Secondly, the risk of a financial crisis is to be diminished by proper regulations of the financial market. Generally, the need for regulatory restrictions is not questioned. However, the regulations restraining some activities create incentives to look for loopholes. A good example is given by Engdahl (2008, V): „The original intent of the Basle Accord was to force banks to reduce lending risk. The actual effect for US banks was just the opposite. They soon discovered a gaping loophole - off-balance-sheet transactions, notably derivation positions and securitization." As an effect of securitization „the lending bank now no longer had to worry if the loan would ever be repaid."

Regulation not only creates incentives for financial institutions to look for loopholes but it also makes regulators wonder about the trade-off between making markets safer or making them more effective and credit less expensive. A devoted advocate of financial liberalization was Greenspan as the governor of the Fed. In particular, Greenspan's opinion presented in 1987 to the US House of Representatives Committee on Banking clearly shows what was his choice concerning the trade-off : „,...repeal of Glass-Steagall would provide significant public benefits consistent with a manageable increase in risk" (Engdahl, 2008, III). Greenspan repeated this mantra until final repeal of the act in 1999. The Glass-Steagall Act of 1933 was intended, broadly speaking, to restrict commercial banks from speculative investing in risky assets and from resulting conflicts of interests which laid behind the crash of 1929. According to Kuttner (2007) ,since repeal of Glass-Steagall in 1999 (...) super-banks have been able to re-enact the same kinds of structural conflicts that were endemic in 1920s".

Another example of liberalization of the financial market in the US is the decision by the Fed in 1974 to lower to $50 \%$ the margin requirements for the purchase of stocks on credit (Regulation T) - the requirement had been at 100\% since 1934. Even in the face of the dot.com bubble Greenspan repeatedly refused to change the stock margin requirements, although ,influential observers, including financier George Soros and Stanley Fisher, deputy director at the IMF, advocated that the FED let the air out of the credit boom by raising margin requirements" (Engdahl, 2008, III).

These remarks, far from an extensive discussion of financial regulation and liberalization, only illustrate the role which proper regulations play in restricting a conflict 
of interests, excessive accumulation of risks and immoderate credit supply. No doubts, were good regulations in place, any financial crisis would be less probable or less severe.

Moreover, proper regulation must be accompanied by effective supervision. It was clearly missing in the case of the huge sale of non-delivery forward currency contracts by Russian banks before the Russian crisis in 1998 or in the case of the Madoff affair when the Securities and Exchange Commission did not undertake necessary activities. It is true that financial markets become more and more complicated and difficult to control (especially when loosely regulated). This observation may result in defeatist attitudes. Engdahl $(2008$, IV) quotes Greenspan who said: „It is, thus, all the more important to recognize that twenty-first century financial regulation is going to increasingly have to rely on private counterparty surveillance to achieve safety and soundness. There is no credible way to envision most government financial regulation being other than oversight of the process. As the complexity of financial intermediation on a worldwide scale continues to increase, the conventional regulatory examination process will become progressively obsolescent - at least for the more complex banking systems." Engdahl (2008, IV) comment says: „Under the Greenspan Fed, the foxes would be trusted to guard the henhouse."

For the time being let's accept two broad statements. Firstly, market participants are sometimes prone to speculative manias which lead to build-up of asset price bubbles. Secondly, proper regulation and supervision may reduce the risk and severity of a financial crisis. Given that, it is more important for the subject of this paper whether there are any economic, in particular monetary, conditions which would be propitious to financial imbalances.

According to Minsky, a financial crisis is triggered by a factor or an event that is called a displacement. A displacement occurs when investors get excited about something - an invention, such as railroads or the internet, or a war, or a major change of economic policy. It also might be a change in the way the financial market operates; an invention of new financial instruments or changes in the regulatory framework.

What is particularly interesting Minsky (1982: 162) points out that „the relations upon which the monetary authorities base their operations are predicted upon the assumption that a given set of institutions and usages exist. If the operations of the authorities have side effects in that they induce changes in financial institutions and usages, then the relations shift. As a result, the side effects of monetary operation can be quite different from those desired".

In fact, Minsky in his work not only points out at a spectacular event being a displacement but also at ,prosperity” being a product of expansionary policy as a milieu where lending booms and speculation thrive. This is an important aspect of his financial instability hypothesis. „The first theorem of the financial instability hypothesis is that the economy has financing regimes under which it is stable, and financing regimes in which it is unstable. The second theorem of the financial instability hypothesis is that over periods of prolonged prosperity, the economy transits from financial relations that make for a stable system to financial relations that make for an unstable system. In particular, over a protracted period of good times capitalist economies tend to move from a financial 
structure dominated by hedge finance units to a structure in which there is large weight of units engaged in speculative and Ponzi finance"1 Minsky (1992: 7-8).

It seems that both factors - a displacement and prosperity - matter. In the case of the dot.com bubble, for example, it was the development of new technologies which made investors exited but it was also time of ,prosperity" - a long period of low interest rates and credit boom. Sometimes it is, however, difficult to identify an incentive for, ,irrational exuberance" in a particular category of assets. It is not obvious, at least not to me at this stage of research, why the present crisis was rooted in mortgage lending. Anyway, in full consistency with Minsky's hypothesis (even though we may use different terminology) the boom led to very high leverage.

These remarks are not very far from a statement that monetary policy may create conditions which are propitious to the development of financial imbalances. This idea is openly expressed by White (2006: 1): „(...) persistently easy monetary conditions can lead to the cumulative build-up over time of significant deviations from historical norms - whether in terms of debt levels, saving ratios, asset prices or other indicators of „imbalances” The historical record indicates that mean reversion is a common outcome, with associated negative implications for future aggregate demand."

The same idea is presented by Borio and Lowe (2002: 22): ,(...) low and possibly falling inflation together with a high degree of credibility of monetary policy would give little reason for the authorities to tighten policy if they respond only to clear signs of inflationary pressures. Paradoxically, (...) endogenous responses to credible monetary policy increase the probability that latent inflation pressures manifest themselves in the development of imbalances in the financial system, rather than immediate upward pressure on higher goods and services price inflation. Failure to respond to these imbalances, either using monetary policy or another policy instrument, may ultimately increase the risk of both financial instability and subsequently deflation." It seems that the earlier mentioned ,side effects of monetary operation” by Minsky have very much in common with ,endogenous responses to credible monetary policy” by Borio and Lowe.

The suggestion by Borio and Lowe that monetary policy may be a reason for financial distress and that it should respond to imbalances even though goods and services prices remain stable is a good starting point to the next part of the paper, which presents this issue in more detail.

${ }^{1}$ „Hedge financing units are those which can fulfill all of their contractual payment obligations by their cash flows: the greater the weight of equity financing in the liability structure, the greater the likelihood that the unit is a hedge financing unit. Speculative finance units are units that can meet their payment commitments on ,income account" on their liabilities, even as they cannot repay the principle out of income cash flows. Such units need to „roll over” their liabilities (...). For Ponzi units, the cash flows from operations are not sufficient to fulfill either the repayment of principle or the interest due on outstanding debts by their cash flows from operations. Such units can sell assets or borrow" (Minsky, 1992: 7). 


\section{Should monetary policy contradict asset price booms?}

The opinion that monetary policy should consider financial stability as a target independent from price stability and that failure to respond to financial imbalances may be a reason for a crisis is not generally accepted at all. In particular, it does not seem to have been shared by the Fed policymakers. A contradictory view, that central banks should restrict from manipulating asset prices, used to be called „Greenspan's doctrine". This is well expressed by Bernanke and Gertler (2000: 45): „In brief, it is that flexible inflation-targeting provides an effective, unified framework for achieving both general macroeconomic stability and financial stability. Given a strong commitment to stabilizing expected inflation, it is neither necessary nor desirable for monetary policy to respond to changes in asset prices, except to the extent that they help to forecast inflationary or deflationary pressures." Bernanke and Gertler (2000: 14) justify this opinion claiming that ,a key advantage of the inflation-targeting framework is that it induces policymakers to automatically adjust interest rates in a stabilizing direction in the face of asset price instability or other financial disturbances. The logic is straightforward; since asset price increases stimulate aggregate demand and asset price declines reduce it, the strong focus of inflation targeters on stabilizing aggregate demand will result in ,leaning against the wind" - raising interest rates as asset prices rise and reducing them when they fall." This straightforward logic is, however, only a pure academic speculation which not necessarily - and not in fact - has much to do with the reality. It is not only against other professional opinions - such as that by Borio and Lowe above - but it is first of all in a sharp contradiction to the experience of many cases of a financial distress, including the present crisis. Moreover, this false opinion is a corner-stone of a formal model presented by Bernanke and Gertler (2000) which ,scientifically" justifies no need to react in an independent manner to financial market imbalances. A good comment would be a quotation from Engdahl (2007, I): „Greenspan has (...) safely retired, written his memoirs and handed the control (and blame) of the mess to a young ex-Princeton professor, Ben Bernanke. As a Princeton graduate, I can only say I would never trust monetary policy for the world's most powerful central bank in the hands of a Princeton economics professor. Keep them in their ivy-covered towers."

Another argument against activist policy targeted at financial stability is alleged impossibility to differentiate between a bubble and fundamentally sound growth of asset prices. Some difficulties or doubts might exist but economists are not hopeless in this respect - for example, some methods are suggested in the above quotation of Borio and Lowe, a fairly extensive presentations of useful indices contain (EBC, 2005). However, Bernanke and Gertler (2000: 7) argue that „because „fundamental discount rate” is not directly observable, it is in general impossible to know whether there is a non-fundamental component in the current stock price."

Similar opinion on the role of monetary policy to prevent asset bubbles and financial instability is presented by Bordo et al. (2000: 27), who write ,that a monetary regime that produces aggregate price stability will, as a by-product, tend to promote stability of the financial system". 
In these days such opinions seem to be without doubt negatively verified by the experience of the present crisis and the economic situation in the years and months preceding. However, this experience is not a unique precedent at all. Also recommendations for monetary policy to counter build-up of financial imbalances are not a recent idea. Borio and Lowe (2002: 1) maintained that ,in principle, safeguards in the financial sphere, in the form of prudential regulation and supervision, might be sufficient to prevent financial distress. In practice, however, they may be less than fully satisfactory. If the imbalances are large enough, the end-result could be a severe recession coupled with price deflation. While such imbalances can be difficult to identify ex ante, the results presented in this paper provide some evidence that useful measures can be developed. This suggests that, despite the difficulties involved, a monetary policy response to imbalances as they build up may be both possible and appropriate in some circumstances."

Looking at the problem from a specific perspective also White $(2006 \mathrm{a}, 2006)$ gives his support to monetary policy which reacts to symptoms of financial imbalances. White argues that price stabilization which tries to avoid periods of deflation (what is characteristic for definitions of price stability as a central bank's target) sometimes may be too expansionary and it may lead to an asset price bubble. This may happen in a situation of ,good deflation" when prices decrease as an effect of some positive supply shocks such as rapid growth of productivity or - as recently - globalization. However, it is interesting in this context to ask to what degree monetary policy should be more accommodative in case of ,bad deflation” - one induced by a financial crisis and falling demand - without risking it may turn out to have been too easy. This problem will be considered in the next part of the paper.

In spite of its clear commitment to price stability (in a manner criticized by White) also ECB (2005) was in favor of a monetary policy reactive to financial imbalances. The reaction postulated should follow a strategy of leaning against the wind where, the central bank would adopt a somewhat tighter policy stance in the face of an inflating asset market than it would otherwise allow if confronted with a similar macroeconomic outlook under more normal market conditions. In this way a central bank would, already at an earlier stage of market dynamics, err on the side of caution in trying to avoid feeding the bubble with an accommodative policy. It would thus tolerate a certain deviation from its price stability objective in the shorter term in exchange for enhanced prospects of preserving price and economic stability in the future" (ECB, 2005: 58). Such policy should also help avoid too late reaction which would only ,prick the bubble” and thus would trigger a crisis.

An interesting solution in the spirit of leaning against the wind has been applied by the Bank of Spain since 2000. Now it is subject to much interest of other central banks and financial institutions. However, it is an instrument of regulatory and not monetary (interest rate) policy. „The central idea behind Spain's system is to smooth economic peaks and troughs by acting countercyclically. During times of economic growth, the system forces banks to set aside a provision for each new loan in case it goes bad. The theory is that the additional cost will limit excessive growth in lending, as well as force banks to build up a cushion against future losses" (Catan and House, 2008). 
It is worth noticing here that the question of an appropriate monetary policy reaction to financial imbalances may as well pertain to the exchange rate. It is characteristic in this case, however, that a bubble - overvaluation - might be a result of persistently tight and not lax monetary policy. White (2006: 6-7) claims that „monetary tightening in the interests of reducing inflationary pressures could, in some cases, lead to a degree of nominal and real appreciation that would significantly worsen the current account balance. This could increase the likelihood of a future exchange rate crisis (...).”

\section{Monetary policy reaction to a financial crisis}

There are two aspects of a major financial crisis; firstly, a fast and deep fall in asset prices and, secondly, financial instability - a risk of a breakdown of the financial system due to bankruptcy of financial institutions of the systemic importance or disorganization of an important segments of the financial market. A general outcome is usually credit crunch and economic stagnation or recession. It is widely accepted that central bank's role is not to exert an impact on asset prices but to protect the financial system and the financial market from a systemic collapse and to prompt economic recovery. According to Mishkin and White (2002: 16) „financial instability is the key problem facing the policymaker and not stock market crashes, even if they reflect the bursting of an asset price bubble. If the balance sheets of financial institutions are initially strong, then a stock market crash (bursting of a bubble) is unlikely to lead to financial instability. In this case, the effect of a stock market crash on the economy will operate through the usual wealth and cost of capital channels, only requiring the monetary policymakers to respond to the standard effects of stock market decline on aggregate demand." The problem is, however, that asset price bubbles are typically accompanied by excessive lending and leverage, risky investment and weak balance sheets of financial and non-financial, debtor institutions. How much influence asset prices can have on financial stability depends also on some technical aspects of the problem, for example the relative importance of OTC/exchange traded instruments; they are not discussed in this paper.

It is thus typical that bursting of an asset price bubble demands some involvement of the central bank beyond its commitment to maintain price stability or its intent to bar aggregate demand from falling. In such a juncture the central bank acts as a lender of last resort. Although this role of a central bank is essentially uncontroversial, during serious crises it can be addressed towards many financial institutions, take huge amounts of bail-out and become eventually a vast infusion of liquidity to the economy, without much respect to considerations other than avoiding the pending financial catastrophe. Such activity is certainly beyond monetary policymakers response to ,the standard effects of stock market decline on aggregate demand." Unfortunately, these efforts may not be very effective in promoting economic recovery, even when they take the form of quantitative easing, as in Japan.

In ECB's (2005: 58) opinion „one argument in favour of a policy of ,leaning against the wind" is symmetry". This is most welcome as a postulate but when it comes to a crisis it seems there is no much room for symmetry. Moreover, even when anti-bubble 
tightening of the monetary policy would be accepted in principle, the monetary policymaker may be reluctant to raise interest rates. „In any event, any asset price „misalignments” are difficult to identify and cannot be effectively resisted since that would require interest rate increases that would be destructive elsewhere in the economy. Conversely, any slowdown in economic activity associated with an asset price „bust” can be effectively resisted through an easing of monetary policy. This could impart a degree of asymmetry to the conduct of domestic monetary policy in the face of such disturbances,,(White, 2006: 11). This quotation clearly presents why monetary policy tends to be asymmetric. I would only add and repeat that easing would rather not be very effective in promoting economic growth; the central bank, however, supplies abundant liquidity also for the reasons of financial stability.

What might be longer-term results of such loosening of monetary policy? A good answer to this question is given by White (2006: 13-14) who claims that „lower interest rates can enhance ,search for yield". This will particularly be the case for financial institutions (like insurance companies and defined benefit pension funds) that must hit predetermined hurdle rates. This both induces investors to purchase increasingly risky assets, and to use increased leverage to raise rates of return on equity. Such behavior becomes manifest in reductions in risk premium on lower-rated paper and sovereigns, and on the increased availability of low cost finance to support venture capital investments and to purchase asset-backed securities. On the one hand, this encourages aggregate spending and investment as desired. On the other hand, should certain sectors be particularly favorably affected (...) this could set the scene for another burst of credit-fuelled misallocations further down the line."

It seems that the policy of the Fed provides a particularly good example of the mistakes a central bank can make with regard to financial crises. First of all, as presented in the second part of the paper, the Fed promoted hasty liberalization and gave up an effective supervision over financial institutions. Moreover, „Greenspan's doctrine” which opposed any reaction to build-up of asset price bubbles went hand in hand with big and lasting reductions of interest rates after a bubble has burst; for example, low interest rates are believed to have fed the dot.com bubble. The bursting of the bubble and the attack of 9/11 also made the Fed lower its interest rates in the years 2001-2004 which can be considered as an important factor behind the build-up of imbalances unveiled during the present crisis. The policy was clearly asymmetric. When policy tightening eventually came it was rather abrupt and not justified in goods and services prices inflation. It seems that against the doctrine the policy reacted to asset price inflation and ,irrational exuberance”. However, coming too late such a policy shift could only „prick” a bubble. This was the case of policy tightening before March 2000, when internet crisis began, and then when interest rate hikes started in the second half of 2004. All these mistakes were accompanied by strong moral hazard in big financial institutions (and after the liberalization only big ones thrived).

The way the present crisis is managed is based on liquidity injection on the scale not seen ever before. Only between August and November 2008 the Fed's balance grew from 900 billion USD to 2,2 trillion USD. In November 2008 the Fed announced new projects which are to boost the monetary base by another 800 billion USD; the Fed decided to 
buy up to 100 billion USD of debt directly issued by Fannie Mae and Freddie Mac and 500 billion USD of their mortgage-backed securities (MBSs) and it created Term Asset-Backed Securities Loan Facilities (TALF) of 200 billion USD which is to lend against a collateral of ABS (asset-backed securities) backed by newly originated consumer and small business loans. In February 2009 the amount of TALF resources was increased to 1 trillion USD. TALF is to realize the aims of Troubled Asset Relief Program (TARP) passed earlier last year by the Congress - the money was, however, used mainly to bail-out troubled financial institutions. Press comments are not necessarily enthusiastic; „Under the guise of successive new programmes, each with a less memorable acronym than the last, the Fed is substituting its balance-sheet for that of the contracting private financial system to keep the American economy from being starved of credit.” „The MBS purchases are significant; for the first time they turn the Fed into a direct lender to consumers. Many homeowners, though they do not know it, will be sending their monthly mortgage payments to the Fed" (Economist, 2008).

On March $18^{\text {th }}, 2009$ the FED announced that it would purchase 300 billion USD in Treasury debt (what is monetization of huge public deficits and raises questions about future independence of the FED), it would boost its purchases of MBSs to 1.25 trillion USD from previously declared 500 billion USD and it will buy 200 billion USD of debt issued by Fannie Mae and Freddie Mac and not 100 billion USD as announced in November 2008. These steps taken by the Fed are examples of quantitative easing after nominal Fed funds rate has been cut virtually to zero. Money is for nothing, and the Fed is ,pushing the string" now.

Some other central banks are also eager to get credit flowing with the use of quantitative easing. The Bank of England announced on March $5^{\text {th }}, 2009$ that it would buy government securities and private assets for 75 billion pounds (105 billion USD).

The reaction to the crisis by the Fed and the American Treasury were aimed at absorbing troubled assets from the private financial sector, helping financial institutions to reduce their leverage, restoring confidence, reducing premia and yields and making credit flow again. To a degree they were successful - yields and premia declined and there was more confidence in the market. What concerns the „strategic" aims these activities do not seem to be very effective. Money is sticking in financial institutions instead of fuelling new lending and boosting the economy. „But precious little of (...) additional liquidity is finding its way through to households and corporate borrowers. In fact, most of it is now sloshing around the banking system like so much excess ballast. Banks have increase their reserve holdings on deposit with the Fed from $\$ 8$ billion to $\$ 494$ billion. This is $\$ 488$ billion more than the Fed estimates they would ordinarily need for payment clearing and prudential purposes" (Kemp, 2008).

The fact that this money remains idle may reflect an approach to the economy of households, firms and - eventually - financial institutions more realistic than that of the central bank. If the economy has been choked with cheap and too easily accessible credit it does not seem that even more credit is a solution. Of course, preventing the financial system from a collapse and viable firms from bankruptcy due to credit crunch, although not without costs, is a reasonable policy. It is also true that negative market sentiment may be self-fulfilling. When most of the agents decide rightly to cut their excessive 
spending it reduces future incomes and - if we still believe in rational expectations make agents to economize even harder. This is a non-optimal Nash - and Keynes equilibrium. It is thus advisable that the economic policy try to change these pessimistic sentiments. It may use fiscal instruments for that purpose and a reasonably easy monetary stance might help as well. Restrictive monetary policy would aggravate problems. With regard to the Great Depression this last statement is subject to Friedman-Schwartz hypothesis which claims that the depression was so deep and long because monetary policy was not accommodative enough. Having said this I am still convinced that flooding the economy with money, bailing-out fraudulent and irresponsible financial institutions, their managers and stock-holders, keeping alive „zombie” firms and offering more credit to „ninja,,(no income, no job, no assets) households is not the right policy. Hopefully, financial institutions and firms are now more cautious then some central bankers and they are afraid to lose more money even though it is virtually for nothing - but still to be repaid. One may expect, also households should realize their true creditworthiness.

What is going to happen with this enormous amount of high-powered, idle money when the economic situation calms down? Is it going to fuel another ,search for yield" and boost another bubble? Or probably in a changed environment it is going to spur goods and services inflation. In theory, this money could be also „mopped” back by the central bank. In practice, it is now difficult to imagine. This monetary hangover becomes a reason for anxiety which is also expressed in the press: „Having expanded its balance-sheet so rapidly, the Fed may not have the foresight or courage to shrink it fast enough once the crisis passes, and the extra liquidity could fuel an overheating economy" (Economist, 2008).

These risk are now recognized by the academia and central bankers. Issing (2009) writes that ,at a closer look the "Jackson Hole Consensus" raises further questions. Even if the mop up strategy might work initially, by exactly doing "its job" in a financial crisis of limited dimension, because of its asymmetric character it may lay the ground for the next bubble and crisis (and so on)"2. Unfortunately, under the stress no one seems to care.

\section{Conclusions}

Without any respect to elegant, academic theories market participants are not fully rational and markets are not efficient. Periodically there are speculative manias and asset price bubbles grow and burst. Good regulation and effective supervision may considerably make these phenomena less probable or less severe. Monetary policy has its role to play to preserve financial stability, too. A new paradigm for monetary policy is still subject to a debate, such as during the $7^{\text {th }}$ BIS Annual Conference „Whither Monetary Policy?

${ }^{2}$, ,(..) restricting the role of the central bank to a totally passive role in the period of the built-up of a bubble and practically pre-announcing its role as the „saviour” once the bubble bursts represents an asymmetric approach which might imply the risk of creating moral hazard with actors driving the development of asset prices.

What can be called the „Jackson Hole Consensus” (...) is exactly this” (Issing, 2009). 
Monetary Policy Challenges in the Decade Ahead" in June 2008. Anyway, it seems clear that „Jackson Hole Consensus” has lost its” appeal.

Easy monetary conditions may result in excessive lending and financial imbalances even though there is no inflation. Creation of money and credit in the economy should not develop without necessary regulation and surveillance and also without a significant cost of reserve money. Unfortunately, monetary policy focused only on price stability does not guaranty proper conditions as it often turns out to fuel excessive credit expansion. However, the worst problems with keeping money under control might arise during a financial crisis. Once monetary policy is eased and liquidity is expanded enormously, it may be difficult to tighten and mop it up, respectively. Such monetary easing may be a precondition for the next crisis. Shortly speaking, money must always remain a scarce resource. However trivial this statement is, monetary policy of some central banks seems to miss the point.

\section{References}

Bernanke B., Gertler M., Monetary Policy and Asset Price Volatility, NBER Working Paper 7559, 2000.

Bordo M., Dueker M., Wheelock D., Aggregate price shocks and financial instability: an historical analysis, NBER Working Paper 7652, 2000.

Borio C., Lowe P., Asset prices, financial and monetary stability: exploring the nexus, BIS Working Paper no 114, 2002.

Catan T., House J. (2008), Spain’s Bank Capital Cushions Offer a Model to Policy Makers, Universidad Autonoma de Madrid, www.uam.es/personal_pdi/economicas, access 9.02.2009.

EBC (2005), Asset price bubbles and monetary policy, Monthly Bulletin, April 2005.

Economist (2008), Plan C, November 27th, 2008.

Engdahl F.W. (2008 II), The Financial Tsunami, Part II, The Financial Foundations of the American Century, www.financialsense.com/editorials/engdah1/2008, access 24.04.2008.

Engdahl F.W. (2008 III), The Financial Tsunami, Part III, Greenspan's Grand Design, www. financialsense.com/editorials/engdahl/2008, access 24.04.2008.

Engdahl F.W. (2008 IV), The Financial Tsunami, Part IV, Financial Crisis: Asset Securatization - The Last Tango, www.globalresearch.ca, access 12.04.2008.

Engdahl F.W., The Financial Tsunami, Part V, Speculative Onslaught. Crisis of the World Financial System: The Financial Predators Had a Ball, www.globalresearch.ca, access 24.04.2008

Issing O., In search of monetary stability; the evolution of monetary policy, BIS Working Paper no 273, March 2009

Kemp J. (2008), TARP and Fed facilities unravel, http://blogs.reuters.com?great-debate/2008/11/13/ tarp-and-fed-facilities-unravel, access 8. 02.2009

Kuttner, R., Testimony of R.Kuttner Before the Committee on Financial Services, U.S. House of Representatives, Washington, D.C., October 2 $2^{\text {nd }}, 2007$.

Mishkin F.S., White E.N., U.S. Stock Market Crashes and Their Aftermath: Implications for Monetary Policy, Asset Price Bubbles Conference, Federal Reserve Bank of Chicago and The World Bank, Chicago, Illinois, April 23 ${ }^{\text {rd }}, 2002$.

Minsky H., Can „It” Happen Again ?, Essays on Instability and Finance, M.E. Sharpe, 1982

Minsky H.P., The Financial Instability Hypothesis, The Jerome Levy Economics Institute of Bard College, Working Paper no. 74, 1992.

White W.R., Procyclicality in the financial system: do we need a new macrofinancial stabilization framework?, BIS Working Paper no 193, 2006a.

White W.R., Is price stability enough?, BIS Working Paper no 205, 2006. 


\section{Znaczenie polityki pieniężnej dla utrzymania stabilności finansowej}

\section{Streszczenie}

Artykuł wskazuje, jak polityka pieniężna, której celem jest wyłacznie stabilność cen towarów i ustug, może przyczynić się do rozwoju inflacji aktywów i-ostatecznie - do kryzysu finansowego. Ryzyko to jest szczególnie wysokie, gdy sektor finansowy nie jest poddany właściwym regulacjom i skutecznemu nadzorowi. Pochopna liberalizacja, lekceważenie znaczenia urzędowego nadzoru oraz „,doktryna Greenspana”, która negowała potrzebe uwzględnienia stabilności finansowej w sposobie prowadzenia polityki pieniężnej charakteryzowaty politykę FED skutkujaca kryzysem finansowym. Artykut analizuje także znaczenie polityki pieniężnej dla zarzqdzania kryzysem. W reakcji na kryzys następuje obniżka stóp procentowych oraz udzielenie pomocy systemowo ważnym instytucjom finansowym, które traca płynność. Taka polityka, zwłaszcza jeśli prowadzona zbyt dtugo $i$ zbyt radykalnie ułatwiajaca dostep do pieniadza banku centralnego, nie tylko rodzi pokusę nadużycia, lecz także powoduje kolejna fale ,"pogoni za zyskiem " i przyczynia się do narastania kolejnej spekulacyjnej bańki. W konsekwencji polityka pieniężna staje się asymetryczna i procykliczna. Reakcja FED na ostatni kryzys finansowy pozostaje $w$ zgodzie z tym wzorcem typowym dla polityki FED w przeszłości. Tym razem wszakże skala zasilenia gospodarki w płynność oraz wynikajacego stad ryzyka nierównowagi na rynkach finansowych w przyszłości sa bezprecedensowe. Podstawowym wnioskiem, jaki plynie z tego artykułu, jest opinia, że nie jest możliwe utrzymanie stabilnego systemu finansowego oraz zdrowej gospodarki, jeśli pieniadz nie jest zasobem rzadkim. Jakkolwiek trywialne może się wydawać takie stwierdzenie, współcześnie ważne banki centralne, z FED na czele, działaja wbrew tej opinii. 